\section{VP-013安全な腹腔鏡下右副腎摘除を目指して 23日（土）第13会場現在の我々の手技}

\section{香川大学医学部泌尿器科学}

常森 寛行, 宮内 康行, 矢野 敏史, 加藤 环磨, 平間 裕美, 山下 資樹, 乾 政志, 杉元 幹史, 筧 善行

【背景・目的】腹胿鏡下副腎摘除術は、隣接臟器損傷などの深刻な合併症の 可能性を懸念し、若手医師の執刀の機会が腎摘除術に比べて少ない。技術 認定試験においても副腎摘除は腎摘除より合格率が低い。しかし、近年潜 在的原発性アルドステロン症の診断が増加傾向にあることより副腎摘除 術の適応症例も増加傾向にある。そこで、腹㓐鏡下手術経験数の比較的少 ない医師にも安全で確実な腹腔鏡下副腎摘除術の執刀を可能にするため に本術式各ステップを見直し、教育の観点を考慮した実践的ビデオの作成 を試みた。手術手技】基本的に腹腔鏡下前方アプローチに側方アプローチ を加味した方法で施行。ポートは肋骨弓下に設置。肝下面の腹膜より切開 開始し、肝臟外側まで切開線を延長する。肝挙上により肝臟が損傷しそう な場合はさらに切開線を外側に延長する。横隔膜面を剥離面の指標として 広く出す。腹膜を下大静脈に沿って尾側に延長する。副腎周囲の脂肪を一 塊として剥離し、副腎頭側で横隔膜、腰方形筋に沿って剥離する。腎上極 と副腎の間を切離する。下大静脈を剥離し副腎静脈を露出し、血管茎を処 理する。副腎を周囲脂肪と一塊にして尾側へ押し下げ、副腎上極を処理し て副腎を摘出する。【結語】 層の正しい理解、横隔膜面と晹腰筋・腰方形筋 表面をランドマークにすることにより安全な手術が実践できる。

\section{VP-014 後腹膜鏡下右副腎摘出術時の下大静脈損傷に 23日 (土) 第13会場 対して鏡視下に修復し得た 1 例}

\section{大分大学医学部腎泌尿器外科学 \\ 高橋 美香, 野村 威雄, 住野 泰弘, 佐藤 文憲, 三股 浩光} 症例は 60 歳、女性。右アルドステロン症と診断され、当科にて後 腹膜鏡下右副腎摘出術を施行した。副腎中心静脈を結紮切断し腫 瘍を周囲脂肪織と共に剥離している際、右腎静脈頭側の後副腎静 脈を損傷したため、ガーゼ圧迫し手術を継続した。副腎を遊離し、 ガーゼを除去したところ、後副腎静脈根部が抜けており、下大静 脈に約 3 ミリの血管損傷部を認めた。気腹圧を $15 \mathrm{mmHg}$ に上げ、 $5 \mathrm{~mm}$ トロカーを 1 本追加し、出血部位をガーゼで圧迫しながら視 野を確保した。4-0 プロリン糸で出血部位の頭尾側に大きく $Z$ 縫 合をおき、下大静脈を童引して出血をコントロールしえた。さら に 4-0 プロリン糸で損傷部位の近傍にZ 縫合をおいて、最初のプ ロリン糸を除去して結紮した。小出血点を認めたため金属クリッ プで 2 か所補強し止血した。手術時間 6 時間 54 分、出血量は 850 $\mathrm{ml}$ 。鏡視下右副腎摘出術中の下大静脈損傷は開腹移行の主な原因 となるが、今回われわれは、鏡視下に下大静脈損傷を修復しえた のでビデオで供覧する。

\section{VP-015腹腔鏡下左副腎摘除術一当院におけるエ夫一 23日（土）第13会場}

\section{岐阜大学医学部泌尿器科}

横井 繁明, 三輪 好生, 中根 慶太, 佐藤 啓美, 加藤 卓, 清家 健作, 石田 健一郎, 安田 満, 伊藤 慎一, 仲野 正博, 出口 隆

腹腔鏡下副腎摘除術は技術認定制度にも用いられる術式で、すで に標準術式として、手術書にその手順は詳細に記載されている。 左側は脾臓を脱転させたのち腎静脈から立ち上がる副腎静脈を見 極め、その処理を先行させることが、ひとつの key point になって いる。次に副腎の背側を持ち上げ、腰方形筋を確認し両サイドに ある血管を含んだ組織を交互に切離しながら、横隔膜側へと剥離 をすすめる手順へとつながっていく。しかし、副腎静脈の同定や、 3 本の clipping 後に切断できるほどの副腎静脈の十分な剥離、副 腎静脈切断後に背側の腰方形筋を確認する操作は、腎門部に近い が故に慎重を有する操作で、経験の少ない術者にとっては決して 容易な操作では無い。特に背側を持ち上げる際は、その梁さや角 度は不明確で、後面の神経節や、腎の血管の分枝も注意しなけれ ばならない。副㹂静脈の処理を先行させ無い方法は以前から報告 されているが、その手順を再考し、経験の少ない術者にもより分 かり易く安全に施行できると思われる手術手順をビデオで供覧す る

\section{VP-016 \\ 当科で行った鏡視下尿管端々吻合術の 2 例} 23日 (土) 第13会場

\section{大分大学医学部腎泌尿器外科学講座}

安藤 忠助, 野村 威雄, 佐藤 文憲, 三股 浩光

尿管端々吻合術は頻度の低い手術と思われるが、今回当科で経験 した鏡視下尿管端々吻合術の 2 例を報告する。症例 $1: 77$ 歳女性。 右腎孟結石に対する $\mathrm{f}$-TUL 術中に判明した尿管断裂に対して、 そのまま後腹膜鏡下手術に移行し修復を行った。尿管断裂部位を 鋭的切除しスリットを入れた後に5-0 バイクリルで 3 針結節縫合 にて尿管断裂部位を端々吻合し術野で 6fr の D-Jカテーテル留置 を行った。術後 2 ケ月目にD-J カテーテルを抜去し術後 15 ケ月 日の現在、水腎症無く経過している。症例 $2: 45$ 歳女性。背部痛を 主訴として診断された左 U3 部尿管狭窄に対して腹腔鏡下手術を 行った。鏡視下に明らかな尿管狭窄部位を $1.5 \mathrm{~cm}$ 切除し術中迅速 病理で悪性所見が無いことを確認後、術野で鏡視下に6Frの D-J カテーテルを留置し尿管にスリットをいれ 5-OPDSにて 10 針結 節縫合にて尿管を端々吻合した。手術時間は $3: 43$ 、出血 $200 \mathrm{ml}$ で病理学的に狭窄部位は瀻維性狭窄であった。術後 2 ケ月目にD$\mathrm{J}$ カテーテルを抜去し術後 4 ケ月目の現在水腎症無く経過してい る。鏡視下尿管端々吻合術は難易度の高い手術であるが、拡大視 野で確実に端々吻合できる点で有用な術式である。学会当日は症 例 2 のビデオを供覧する。

VP-017

大網巻酪によるCAPD カテーテル閉塞に対 して腹腔鏡下カテーテル先端引き出し整復術 が有効であった 1 例

西神戸医療センター泌尿器科"1, 西神戸医療センター腎臓内科 ${ }^{27}$ 上山 裕樹 ${ }^{1}$, 井口 亮 ${ }^{12}$, 金丸 聰淳 ${ }^{12}$, 伊藤 哲之 ${ }^{17}$, 塩月 優子 ${ }^{2}$, 田中 美佐 ${ }^{21}$, 大山 敦嗣 2 '

症例は 15 歳、女性。学校検尿で尿蛋白陽性にて 7 月下旬近医受診した。採血 で $\mathrm{Hb} 5.9 \mathrm{~g} / \mathrm{dl} 、 \mathrm{Cr} 11.68 \mathrm{mg} / \mathrm{dl}$ を指摘され当院紹介受診した。両腎ともに萎 縮腎であり、永久透析導入が必要と判断し、8月 SMAP 法施行した。 5 日後 にカテーテル上方変位認め、出口部作成時にガイドワイヤーにて整復試みる も困難であったが、注排液に問題ないことを確認し手術を終了した。透析開 始 5 日目頃より注排液不良を認めていたが、夜間 APD 開始後よりほとんど 排液ができなくなったため腹腔鏡下 CAPD カテーテル整復術を施行した。 カメラポートを右下腹部に、 $5 \mathrm{~mm}$ のポートを豚下 4 横指に留置した。カテー テル周囲に巻きついた大網は鈷子で剥離できたが、カテーテル内部に迷入し

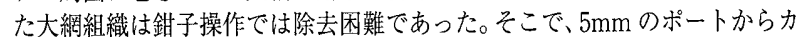
テーテル先端を体外に引き出し、用手的にカテーテル内の大網組織を除去し た。カテーテルを腹壁に固定(P-WAT)して手術を終了した。その後カテー テルの位置異常や注排液不良などのトラブルは認めていない。腹沿鏡下 CAPD カテーテル先端引き出し整復術は、従来の下腹部切開示指挿入矯正法 や小切開大網切除術と比べ、安全から低侵襲であり、カテーテル異常の原因 診断、治療において有効であると考えられた。手術手技を供覽する。
VP-018 23日 (土) 第13会場
3Dソリッドモデルを利用したドライボック スでの腹腔鏡手術トレーニングと術前シミュ レーション

\section{獨協医科大学越谷病院泌尿器科}

宋 成浩, 青木 裕章, 小川 一栄, 佐藤 両, 芦沢 好夫, 小堀善友, 八木 宏, 新井 学, 岡田 弘

【目的】我々は，画像検査から作成した光造形モデルを用いたドライ ボックス型腹腔鏡手術シミュレーターを作成し、腹胿鏡手術トレー ニングに利用してみた。【方法】各症例の MD-CT から得られた DICOM ファイルを用いて、(株) JMC の協力のもと、腎尿路の光造形 モデルを作成し、モデルの固定可能なドライボックスの作成を行っ た。外観は腹部外皮(皮䖉)の形態を模して作成された。複数のポー 卜孔を作成、実際の手術に模した位置からカメラ、鉜子の挿入が可 能とした。【結果】上部尿路と骨盤内腹腔鏡手術のトレーニングと術 前シミュレーションが可能となった。特に鉗子とカメラの動きが、 樹脂製の外皮を通して確認できた。最も適切なカメラの位置をシ ミュレーションすることができた。さらに、シングルポート手術を 行う場合の機械の動きをシミュレーションするのに最適であった。 【考察と結語】今回報告するドライボックスは、鉗子挿入孔、臓器位 置の調整が可能であり、実際の手術に近い使用感があるように工夫 をした。トレーニングならびに術前シミュレーションでの、この新 しいドライボックスの有用性についての検討をした。 